\title{
Predicting the Outcome of Microsurgical Resection of Olfactory Groove Meningiomas (OGMs): Experience at Benha University Hospital
}

\author{
MOATAZ A. ELAWADY, M.D.; MAHMOUD M. WAHDAN, M.D. and MOHAMMED E. ELHAWARY, M.D. \\ The Department of Neurosurgery, Faculty of Medicine, Benha University
}

\begin{abstract}
Background: Radical excision of olfactory groove meningioma is the goal of microsurgery but faces some challenges such as the hypersostotic bone and paranasal sinus invasion with resulting Cerebrospinal Fluid (CSF) leak and infection making high recurrence rate.
\end{abstract}

Aim of Study: The aim of the present study was to identify factors predicting the outcome for patients with a diagnosis of OGMs undergoing microsurgical resection and to examine whether there is a general benefit of such microsurgery.

Patients and Methods: A total number of 28 patients were microsurgically operated for OGMs at the Neurosurgery Department of Benha University Hospital between January 2012 and December 2018.

Results: No patient characteristics, such as age, sex or presenting symptoms could be considered predictive for the post-operative outcome. Of the tumor-related characteristics only the presence of skull base invasion and the Simpson grading of removal were considered negative predictors for the outcome.

Conclusions: Microsurgical removal of the OGMs is effective and save with very little morbidity and low risk of post-operative recurrence provided that it is done totally with complete reconstruction of the skull base.

Key Words: OGMs - Microsurgery - Skull base.

\section{Introduction}

MENINGIOMA comprises $13-30 \%$ of all intracranial neoplasms $[\mathbf{1 , 2}]$. Olfactory Groove Meningioma (OGM) is not uncommon location representing between 4 to $10 \%$ of such tumors and arise in the midline over the cribriform plate and frontosphenoidal suture between the crista galli and the tuberculum sellae [3]. OGMs attain large size before being symptomatic in the form of mental changes and visual field defects making late diagnosis is the role $[2,4]$.

Correspondence to: Dr. Moataz A. Elawady, The Department of Neurosurgery, Faculty of Medicine, Benha University
Radical excision of OGMs is the goal of microsurgery but faces some challenges such as the hypersostotic bone and paranasal sinus invasion with resulting Cerebrospinal Fluid (CSF) leak and infection making high recurrence rate $5-41 \%$ [2]

The aim of the present study was to identify factors predicting the outcome for patients with a diagnosis of OGMs undergoing microsurgical resection and to examine whether there is a general benefit of such microsurgery.

\section{Patients and Methods}

Study design: This is a retrospective single centre analytical study of all patients who was microsurgically operated for OGMs at the Neurosurgery Department of Benha University Hospital between January 2012 and December 2018.

Patients: A total number of 28 patients were microsurgically operated for OGMs at the Neurosurgery Department of Benha University Hospital between January 2012 and December 2018.

Pre-operative work: For all patients, demographic data were obtained regarding age, sex, residence, marital status and comorbidities. Complete general and neuro-ophthalmological examination and investigations such as brain Magnetic Resonance Imaging (MRI) and Computed Tomography $(\mathrm{CT})$ of the paranasal sinuses were obtained for all patients. Any patient with visual complain was examined by an expert ophthalmologist regarding the fundus and visual field. Pre-operative Kanofsky Performance Score was accurately measured and recorded for each patient.

According to size tumors were classified as small when tumor size on MRI was less than $2 \mathrm{cc}$, 
medium with 2-4cc tumor size, large with 4-6cc tumor size and giant when tumor size exceeds $6 \mathrm{cc}$.

Operative details: The bilateral subfrontal approach was done for 16 patients when the tumor was sizable and the unilateral subfrontal approach was done for the small-to-medium 12 tumors [5].

- Patient position: The patient is placed in the supine position on the operating table with the head fixed in a three-pin Mayfield headholder. The patient's neck is retroflected, resulting in an angle of approximately $20^{\circ}$ between the plane of the anterior cranial base and the vertical plane of the axis. This position allows the frontal lobe to fall away from the anterior cranial floor and facilitates good venous drainage during surgery. Fine adjustments of the patient's position are accomplished by tilting the operating table.

- Skin incision: After a precise definition of the frontal anatomic landmarks (e.g., the orbital rim, supraorbital foramen, temporal line and zygomatic arch), the line of the incision is marked on the skin. Thereafter the skin is prepared with Betadine solution. The skin incision, usually placed behind the hairline, begins less than $1 \mathrm{~cm}$ anteriorly to the tragus on the side of the craniotomy and extends medially in a curvilinear fashion above the superior temporal line, slightly crossing the midline by 1 or $2 \mathrm{~cm}$ in unilateral incision or to the opposite tragus in bilateral incisions. As the skin is reflected anteriorly along with the pericranium and retracted with temporary fishhooks, the galea will merge with the superficial layer of the temporalis fascia. At the supraorbital ridge, care should be taken to identify and preserve the supraorbital nerve and the supraorbital artery passing along the medial third of the superior orbital rim. Upon retraction of the skin-aponeurosis flap, a semilunar incision is made through the pericranium under the frontozygomatic process, $0.5 \mathrm{~cm}$ superior to the temporal line and diagonally along he frontal lobe. At this point the pericranium is separated from the inferior surface of the frontozygomatic process and reflected. Careful dissection and minimal retraction of the orbicular and frontal muscular layer are essential to avoid a postoperative periorbital hematoma. Before starting the craniotomy local hemostasis must be performed.

- Craniotomy: The craniotomy is started using a high-speed drill, with the placement of a single frontobasal burr hole at MacCarty's point, posterior to the temporal line, just above the frontosphenoid suture or at the frontozygomatic point. This is the keyhole that represents an anatomic window that provides access to the anterior cranial base. A high- speed craniotome is then used to create the bone flap, which must extend anteriorly to the origin of the frontozygomatic process and parallel to the temporal line. The craniotome is directed from the first hole superiorly and describes a curve in the frontal area. The limits are the supraorbital foramen medially and the sphenoid wing laterally. The lateral border of the frontal sinus has to be considered during craniotomy. Continuous irrigation during the drilling avoids thermal damage to the brain and allows more precise bone cutting. A hand-held retractors is used to provide the necessary soft-tissue retraction and exposure as the craniotome is turned around the flap. If dissection of the dura cannot be easily accomplished from a single burr hole, then a second burr hole can be made. Careful separation of the dura from the inner surface of the bone using a blunt dissector avoids laceration of the dura mater. An important next step is the drilling of the inner edge of the orbital roof protuberances with a highspeed drill (unroofing) to optimize the exposure to the anterior cranial fossa and the angle to reach the frontobasal area.

- Dural opening: Typically, the dura is opened in a $\mathrm{C}$-shaped fashion, under the operating microscope, with its base toward the cranial base, parallel along the orbital floor. It is reflected anteriorly and anchored with stay sutures. A clearance of several millimeters should be allowed between the bone margin and the dural incision, to facilitate the final closure of the dura. When it is reflected, special attention should be paid in the proximity of the superior sagittal sinus. Elevation and retraction of the frontal lobe pole will subsequently expose the target area at the frontal base of the skull.

- Tumor removal: The arachnoid is slightly incised with an arachnoidal hook, or as an alternative, bipolar forceps could be used to make a hole in the arachnoid membrane. It is important to follow the arachnoid plane using the microforceps and the suction tip to achieve a stepwise dissection until the lesion is reached. During these surgical maneuvers, when a certain degree of brain retraction is needed, a self-retaining brain retractor attached to a flexible arm permits fine adjustment, preserving the normal tissue. Hemostasis must be accurately controlled during the intracranial procedure, and the intradural space should be filled with Ringer's solution at body temperature. Sometimes the unilateral subfrontal approach could be used for some asymmetric midline lesions with the possibility of cutting the falx above the crista galli and saving the superior sagittal sinus to gain access also to the contralateral side. After the lesion has been managed, the dural incision is sutured water-tight 
using continuous sutures. The bone flap is appositioned medially and frontally without bony distance to achieve the optimal cosmetic outcome and fixed with low-profile titanium plates and screws.

- Closure: After final verification of hemostasis, the galea with the subcutaneous layers are reapproximated with several interrupted absorbable sutures and the skin is closed with a Donati suture. At the end of the procedure the Mayfield pin headrest is removed and general anesthesia is reversed.

Hospital stay: For all patients at least 48 hours of post-operative inpatient care was the role and it could be extended thereafter according to the early post-operative course.

Follow-up: Patients with at least 6-month postoperative follow-up were included in this study. Follow-up visits were arranged to be weekly in the first month and monthly thereafter. In each visit complete general and neuroophthalmological examination were done. Post-operative MRI study was obtained at the end of 6-month follow-up and yearly thereafter.

\section{Results}

A total number of 28 patients were microsurgically operated for OGMs at the Neurosurgery
Department of Benha University Hospital between January 2012 and December 2018. Out of them, there were 17 females and 11 males with age ranging between 33 and 70 years. In 26 patients De Novo OGMs were encountered in 2 cases, there were recurrent OGMs.

According to tumor size, 7 tumors were small, 5 were medium, 12 were large and 4 were giant. Histological types of the tumors were transitional in 10 patients, fibroblastic in 10 patients, meningiothelial in 6 patients and psamomatous in 2 patients. WHO grading of the tumors was grade I in 21 patients, grade II in 5 patients and grade III in 2 patients.

Simpson Grade I resection was achieved in 10 cases and grade II in 18 cases. No death occurred. Cerebrospinal fluid rhinorrhea occurred in two patients and responded to 2 weeks of conservative treatment in the form of elevated head position, acetazolamide and temporary lumbar drain. No cases needed revision reconstruction surgery, there were no intracranial infection occurred postoperatively. Tumor recurrence was observed in two patients after a follow-up of $14.75 \pm 6.48$ (636) months with grade II Simpson and when revised microsurgically, grade I was achieved and no further tumor recurrence after 6 and 8 months follow-up.

Table (1): Patient criteria.

\begin{tabular}{|c|c|c|c|c|c|c|c|c|c|c|}
\hline Patient & Sex & Age & Presenting symptoms & Type & Size & $\begin{array}{l}\text { Simpson's } \\
\text { grading }\end{array}$ & $\begin{array}{l}\text { WHO } \\
\text { grade }\end{array}$ & $\begin{array}{l}\text { Histological } \\
\text { type }\end{array}$ & $\begin{array}{l}\text { Follow-up } \\
\text { (months) }\end{array}$ & Outcome \\
\hline 1 & $\mathrm{~F}$ & 33 & Seiyures/headache & De Novo & Large & I & I & Meningiothelial & 12 & Good \\
\hline 2 & $\mathrm{~F}$ & 55 & Seizures/blurred vision & De Novo & Small & I & I & Transitional & 18 & Good \\
\hline 3 & M & 65 & Seiyures/headache & De Novo & Small & I & I & Fibroblastic & 10 & Good \\
\hline 4 & $\mathrm{~F}$ & 45 & Seizures/blurred vision & De Novo & Medium & I & I & fibroblastic & 16 & Good \\
\hline 5 & $\mathrm{~F}$ & 50 & Seiyures/headache & De Novo & Large & II & I & Meningiothelial & 9 & Good \\
\hline 6 & $\mathrm{~F}$ & 52 & Blurred vision & De Novo & Medium & II & III & Transitional & 24 & Blurred vision \\
\hline 7 & M & 70 & Seiyures/headache & De Novo & Large & II & II & Fibroblastic & 12 & Blurred vision \\
\hline 8 & M & 58 & Blurred vision & De Novo & Large & I & I & Transitional & 12 & Good \\
\hline 9 & $\mathrm{~F}$ & 42 & Seiyures/headache & De Novo & Giant & II & I & Psamomatous & 6 & Good \\
\hline 10 & $\mathrm{~F}$ & 35 & Seizures/blurred vision & De Novo & Giant & II & II & Fibroblastic & 24 & Blurred vision \\
\hline 11 & $\mathrm{~F}$ & 38 & Seiyures/headache & De Novo & Large & II & I & Meningiothelial & 36 & Good \\
\hline 12 & M & 57 & Accidentally discovered & De Novo & Large & $\mathrm{I}$ & I & Transitional & 9 & Good \\
\hline 13 & $\mathrm{~F}$ & 37 & Accidentally discovered & De Novo & Medium & II & I & Psamomatous & 10 & Good \\
\hline 14 & M & 57 & Blurred vision & De Novo & Small & II & III & Transitional & 12 & Blurred vision \\
\hline 15 & M & 52 & Seiyures/headache & De Novo & Large & II & I & Fibroblastic & 12 & Good \\
\hline 16 & $\mathrm{~F}$ & 40 & Seiyures/headache & De Novo & Giant & II & II & Transitional & 12 & Recurrence \\
\hline 17 & M & 45 & Seiyures/headache & De Novo & Large & I & I & Meningiothelial & 18 & Good \\
\hline 18 & $\mathrm{~F}$ & 42 & Seizures/blurred vision & De Novo & Small & II & I & Transitional & 18 & Blurred vision \\
\hline 19 & $\mathrm{~F}$ & 44 & Seiyures/headache & De Novo & Large & II & I & Fibroblastic & 20 & Good \\
\hline 20 & M & 46 & Accidentally discovered & De Novo & Large & II & I & Transitional & 22 & Good \\
\hline 21 & $\mathrm{~F}$ & 37 & Seiyures/headache & De Novo & Medium & II & I & Fibroblastic & 20 & Blurred vision \\
\hline 22 & M & 39 & Blurred vision & De Novo & Medium & I & I & Transitional & 12 & Good \\
\hline 23 & $\mathrm{~F}$ & 40 & Blurred vision & De Novo & Giant & II & II & Fibroblastic & 15 & Recurrence \\
\hline 24 & M & 42 & Seizures/blurred vision & De Novo & Small & II & I & Meningiothelial & 14 & Blurred vision \\
\hline 25 & $\mathrm{~F}$ & 41 & Seiyures/headache & De Novo & Large & II & I & Fibroblastic & 14 & Good \\
\hline 26 & $\mathrm{~F}$ & 45 & Seiyures/headache & De Novo & Large & II & I & Meningiothelial & 12 & Good \\
\hline 27 & $\mathrm{~F}$ & 41 & Seiyures & Recurrent & Small & 1I & I & Fibroblastic & 8 & Good \\
\hline 28 & $\mathrm{~F}$ & 41 & Seiyures/headache & Recurrent & Small & II & I & Transitional & 6 & Good \\
\hline
\end{tabular}


Table (2): Presenting symptoms in our patients.

\begin{tabular}{lc}
\hline Symptom & Number of patients $(\%)$ \\
\hline Seizures & $21(75)$ \\
Headache & $14(50)$ \\
Blurred vision & $10(35.7)$ \\
No symptom & $3(10.7)$ \\
\hline
\end{tabular}

Table (3): Simpson's grading system.

\begin{tabular}{llc}
\hline Grade & \multicolumn{1}{c}{$\begin{array}{c}\text { Definition of corresponding } \\
\text { resection }\end{array}$} & $\begin{array}{c}\text { Number of } \\
\text { patients }\end{array}$ \\
\cline { 2 - 3 } I & $\begin{array}{l}\text { - Macroscopically complete resection } \\
\text { with excision of dural attachment and } \\
\text { abnormal bone. }\end{array}$ & 5 \\
II & $\begin{array}{l}\text { Macroscopically complete resection } \\
\text { with coagulation of dural attachment. }\end{array}$ & 21 \\
III & - Macroscopically complete resection \\
& $\begin{array}{l}\text { without resection or coagulation of } \\
\text { its attachment. }\end{array}$ & \\
IV & - Subtotal resection. & 0 \\
V & - Simple decompression of the tumor. & 0 \\
\hline
\end{tabular}
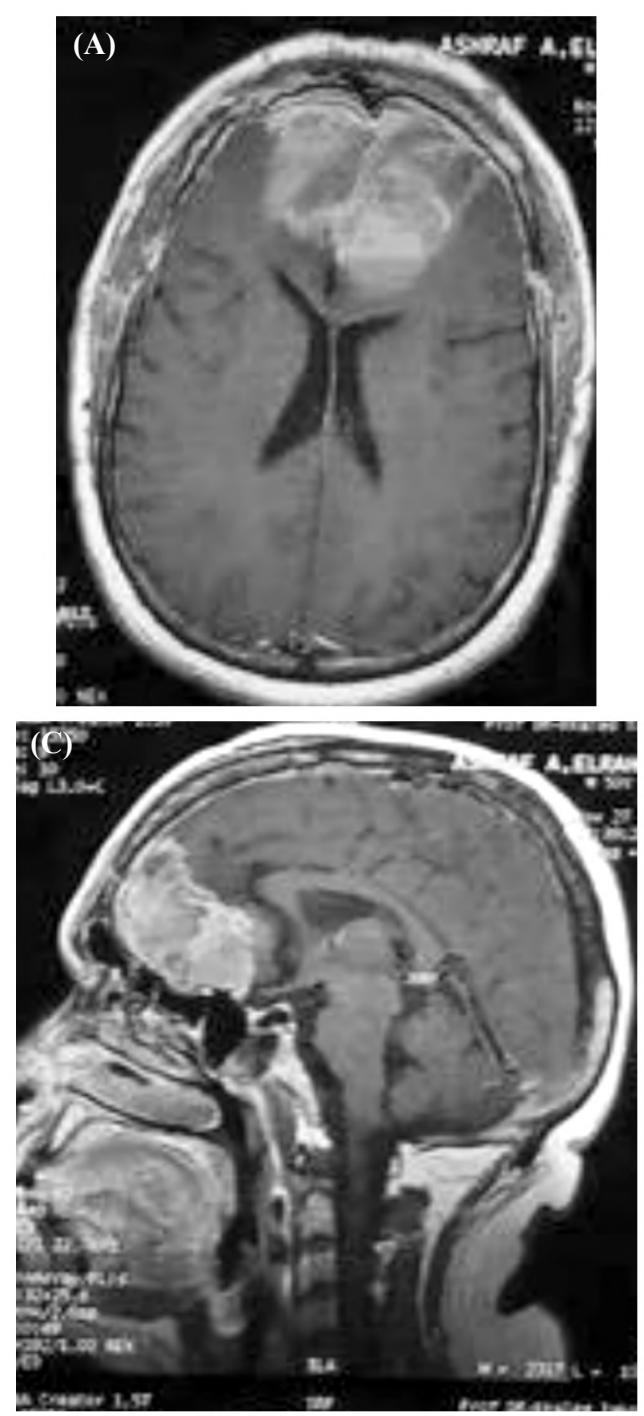

Fig. (2): MRI images A- Pre-op axial, B- Pre-op coronal, C- Preop sagittal and D- Post-operative sagittal of OGM.

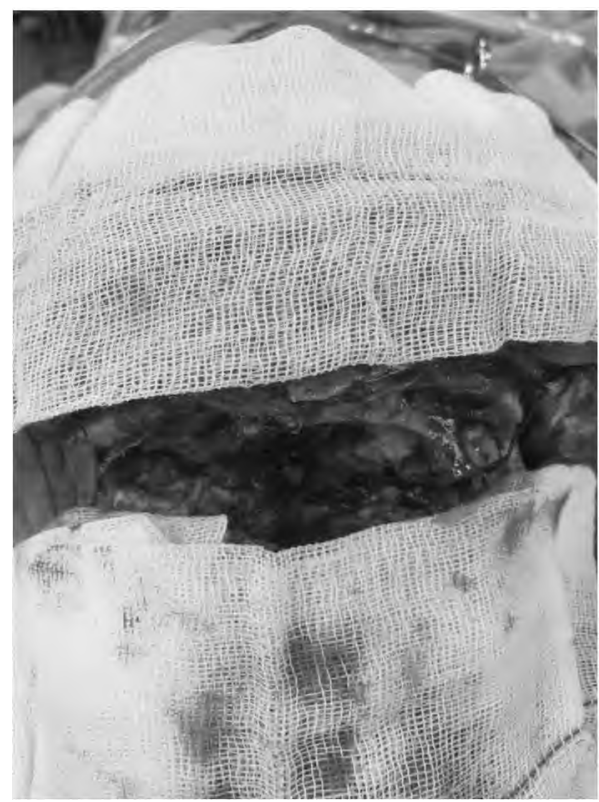

Fig. (1): Intraoperative photograh of bilateral subfrontal approach to remove OGM.
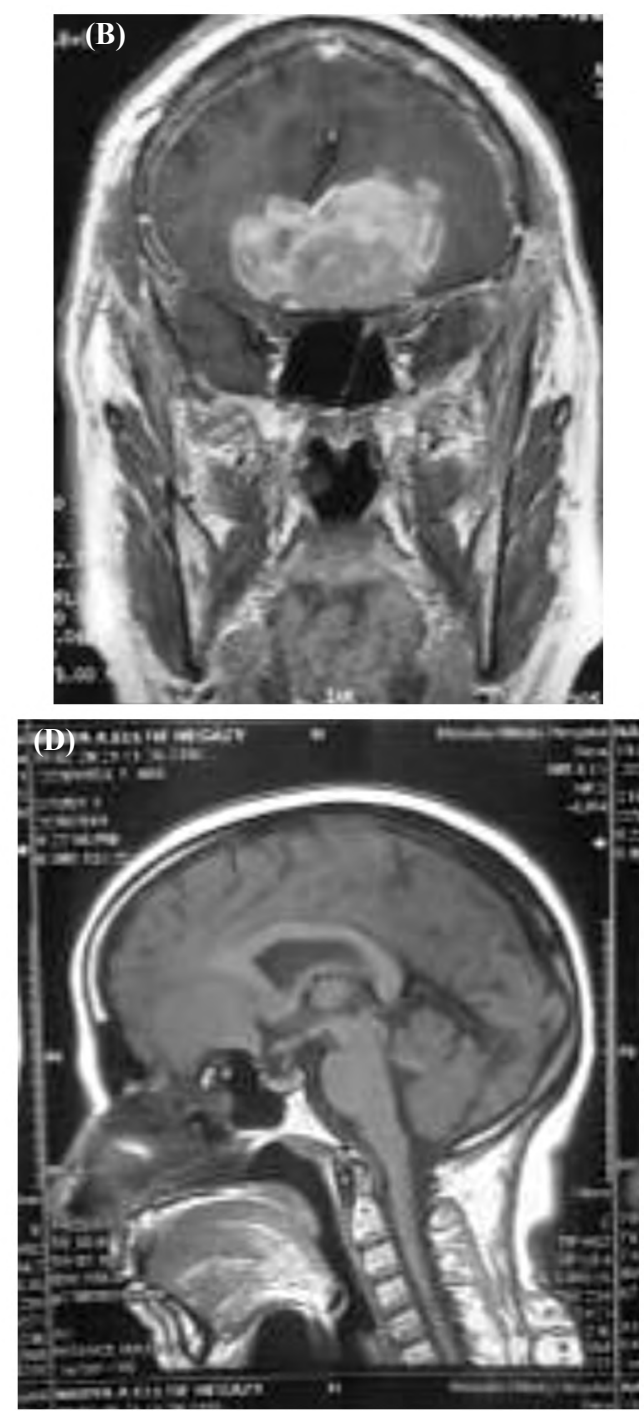


\section{Discussion}

Meningiomas that compress the frontal lobes, as OGMs are mostly "silent," and are thus likely to be misdiagnosed or overlooked [2]

There are several studies that describe in detail the clinical findings, types of neurosurgical approaches, results and rate of recurrences. The most comprehensive studieswere those of Solero et al., [6] with 98 cases, the study of Spektor et al., [7], with 80 patients, the study of Nakamura et al., [8] 82 cases; the study of Bassiouni et al., [9], 56 cases and the study of Romani et al., with 66 cases [10]

We used the subfrontal approach either the unilateral (in 12 patients) or the bilateral (in 16 patients) according to the size of tumor on preoperative MRI. The frontolateral approach could be also an option. It allows a good visualization of the optic nerves, chiasm and anterior cerebral arteries and doesn't require a prolonged retraction of the frontal lobe [11].

Post-operative mortality reached $22 \%$ and morbidity to $25 \%$ in some seies $[3,12]$. In our study, no death occurred. Cerebrospinal fluid rhinorrhea occurred in only two patients. Recurrence rate ranged from 0 to $10 \%$. The recurrence may reflect incomplete resection of the tumor due to the difficulties in resection or be the result of ethmoidal bone invasion with incomplete removal of infiltrated bone. Only 2 of our denovo 26 patients showed recurrence but according to Obeid and Al-Mefty, (13) the OGM could have a high rate of late recurrence (average 23\%).

Although Liu et al., [14] and Liang et al., [15] stated that radical excision of OGMs (Simpson grade I) should be the goal of microsurgery, this is not always feasible.

In our study, no patient characteristics, such as age, sex or presenting symptoms could be considered predictive for the post-operative outcome. Of the tumor-related characteristics only the presence of skull base invasion and the Simpson grading of removal were considered negative predictors for the outcome.

These results are in accord with those of others who studied the prognostic factors of microsurgical treatment of meningiomas in general $[16,17]$.

Recently, it has been shown that the Simpson grade is not universally applicable to all meningiomas. So, there has been a trend towards more conservative treatment for meningiomas, mainly, a staged treatment with debulking followed by adjuvant treatment might be preferable in order to minimize post-operative morbidity and mortality, especially in skull-base meningiomas [8]. The predictive factors of poor outcome identified in this study may help neurosurgeons to identify those patients who may fare better with staged treatment.

\section{Conclusions:}

Microsurgical removal of the OGMs is effective and save with very little morbidity and low risk of post-operative recurrence provided that it is done totally with complete reconstruction of the skull base.

\section{References}

1- MAURICE-WILLIAMS R.S. and DUNWOODY G.: Late diagnosis of frontal meningiomas presenting with psychiatric symptoms. Br. Med. J. (Clin. Res. Ed), 296: 17856, 1988.

2- RAVIKANTH R., PINTO D.S. and MATHEW S.: Olfactory groove meningioma masquerading as psychiatric disturbances. Indian J. Psychiatry. Jul.-Sep., 60 (3): 367 9,2018

3- CIUREA A.V., IENCEAN S.M., RIZEA R.E., et al.: Olfactory groove meningiomas. Neurosurgical Review, Volume 35, Issue 2, pp. 195-202, 2012.

4- BABU R., BARTON A. and KASOFF S.S.: Resection of olfactory groove meningiomas: Technical note revisited. Surg. Neurol., 44: 567-72, 1995.

5- De DIVITIIS O., IACOPINO D.G., SOLARI D., et al.: Subfrontal Approaches. In: Cranial, Craniofacial and Skull Base Surgery. Cappabianca P o Califano L Iaconetta G (Ed.): Springer, 2, 17-27, 2010.

6- SOLERO C.L., GIOMBINI S. and MORELLO G.: Suprasellar and olfactory meningiomas. Report on a series of 153 personal cases. Acta. Neurochir. (Wien), 67: 181-94, 1983.

7- SPEKTOR S., VALAREZO J., FLISS D.M., et al.: Olfactory groove meningiomas from neurosurgical and ear, nose, and throat perspectives: Approaches, techniques, and outcomes. Neurosurgery, 57 (4 Suppl): 268-80, 2005.

8- NAKAMURA M., STRUCK M., ROSER F., VORKAPIC P. and SAMII M.: Olfactory groove meningiomas: Clinical outcome and recurrence rates after tumor removal through the frontolateral and bifrontal approach. Neurosurgery, 60 (5): 844-52, 2007.

9- BASSIOUNI H., ASGARI S. and STOLKE D.: Olfactory groove meningiomas: Functional outcome in a series treated microsurgically. Acta. Neurochir. (Wien), 149 (2): 109-21, 2007.

10- ROMANI R., LEHECKA M., GAAL E., et al.: Lateral supraorbital approach applied to olfactory groove meningiomas: Experience with 66 consecutive patients. Neurosurgery, 65 (1): 39-52, 2009.

11- EL-BAHY K.: Validity of the frontolateral approach as a minimally invasive corridor for olfactory groove meningiomas. Acta. Neurochir. (Wien), 151 (10): 1197-1205, 2009. 
12- AGUIAR P.H., TAHARA A., ALMEIDA A.N., et al.: Olfactory groove meningiomas: Approaches and complications. J. Clin. Neurosci., 16 (9): 1168-73, 2009.

13- OBEID F. and AL-MEFTY O.: Recurrence of olfactory groove meningiomas. Neurosurgery, 53: 534-43, 2003.

14- LIANG R.S., ZHOU L.F., MAO Y., et al.: Microsurgical removal of olfactory groove meningiomas. Zhonghua Zhong Liu Za Zhi Jan., 33 (1): 70-5, 2011.

15- LIU Y., LIU M., CHEN Y., et al.: Microsurgical total removal of olfactory groove meningiomas and reconstruction of the invaded skull bases. Int. Surg., May-Jun., 92 (3): 167-73, 2007.

16- FERNANDEZ C., NICHOLAS M.K. and, ENGELHARD H.H., et al.: An analysis of prognostic factors associated with recurrence in the treatment of atypical meningiomas. Adv. Radiat. Oncol., 1: 89-93, 2016.

17- LEMÉE J.M., CORNIOLA M.V., Da BROI M., et al.: Extent of Resection in Meningioma: Predictive Factors and Clinical Implications. Sci. Rep., 9: 5944, 2019.

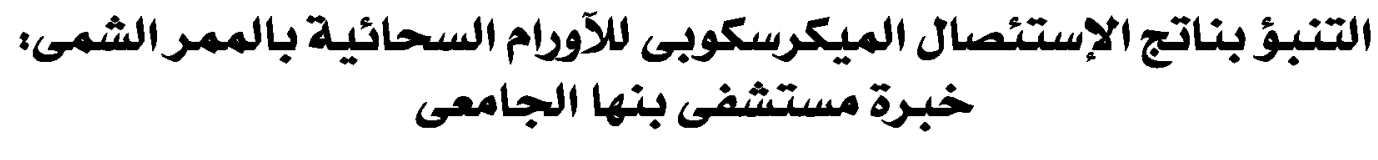

الخلفية العلهية: إن الإستئصال الجذرى للآقدام السحائية بالممر الثمى هو الهدف من الجراحة الميكروبكوبية ولكن قد يعترض ذلك

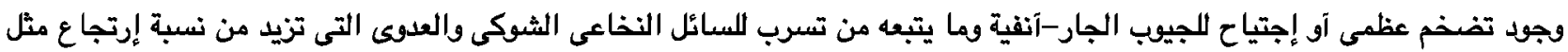
هذه الآقرام.

الهدف من الدراسة: تهدف هذه الدراسة إلى محاولة إيجاد العوامل التي تتباً بناتج الإستئصال الميكروبكوبى للآورام السحائية بالممر

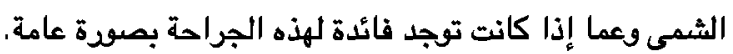

المرضنى ووسائل البحث: آجريت هذه الدراسة في مستشفى بنها الجامعى على بـ مريض آجريت لهم جراحة ميكروبكوبية لإستئصال

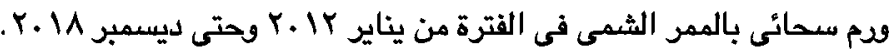

النتائج: لم يتم ريط آى من العوامل الخاصة بالمريض مثل العمر آو الجنوبسة آو الآعراض المصاحبة كعوامل تنبؤية ومن العوامل الخاصة بالومث تم ربط درجة إجتياح عظام قاع الجمجمة ولدرجة إستئصال الوفم كعوامل سلبية للناتج الجراحس.

الخلاصدة: للجراحة الميكروبكوبية لود فعال فى إستئصال الآمدام السحائية بالممر الثمى إذا ما آمكن إستئصال الورم تماماً مع إعادة تشكيل قاع الجمجمة لتجنب نسبة الإرتجاع العالية. 